\title{
The use of ceramic product derived from non-halal animal bone: is it permissible from the perspective of Islamic law?
}

\begin{abstract}
A ceramic product derived from the bones of non-halal animal has become an issue for Muslims in terms of its status whether it is halal or haram. The status can be determined by scrutinizing the transformation process or namely as istihālah either a complete change (istiḥālah kāmilah) or an incomplete change (istiḥālah ghayr kāmilah). This research used the qualitative research method via the approach of document analysis to examine various opinions of classical and current Islamic jurists on the status of using ceramic products derived from the bones of non halal animal according to the Islamic law. The research discovers an alternative method of processing ceramic products from animal bones through istihâalah. It is a transformation of filthy or haram materials into other materials which includes physical appearance and its properties such as odor, taste and color.
\end{abstract}

Keyword: Ceramic products; Bone China; Water filter; Non-ḥalāl, Animal bone; Istihāalah; Fiqh-jurisprudence; Halal industry 